\title{
Tort Law in Practice: Appearance and Reality in Reforming Periodical Payments of Damages
}

Richard Lewis*

\section{Introduction}

This chapter is distinct from almost all the others in this book and is part of a different tradition in tort scholarship. This is because it is founded on experience of the practical operation of the tort system and because it refers to empirical work which describes how that system operates. The other chapters are not as directly concerned with who actually pays and in what manner for personal injury-the most important type of tort claim as far as most practitioners are concerned. The conference for which this chapter was prepared exposed a gulf between the views of such practitioners and the particular academic discourse which predominated in the papers presented at the event. This gulf was brilliantly highlighted in a devastating after-dinner speech by Justice lan Binnie of the Supreme Court of Canada. This chapter attempts to bridge the divide by setting a particular 'emerging issue in tort law' in its wider economic and political context, and reflecting on both its academic and its practical implications. It also outlines the basis for comparative work by noting legislation in Canada which is similar to that in the UK which forms the focus for this study.

This chapter deals with the recently renewed attack upon paying damages for personal injury in the form of a lump sum as opposed to periodically. Almost twenty years ago the concept of a structured settlement was imported from North America and first used in the UK in order to provide continuing lifetime payments for seriously injured claimants. ${ }^{1}$ However, the idea was slow to develop. Proposals for a structure were easily defeated if either of the parties objected. To counter this, legislation has now removed the veto: taking into account the needs of the claimant, a judge can make a periodical payments order even if it is against the wishes of either or even both of the parties. The court must consider making such an order in any case involving future financial loss. The lump sum award is thus under attack.

I will look at the impact of this reform on the settlement system and the bargaining power of the parties. The relationship between the new legislative regime and the existing approach to structured settlements is examined. Looking at the wider context, the article reveals that in this reform there was an inadequate assessment of the economic and financial factors which affect the payment of damages. In particular, the cost to liability insurers of changing the form of payment was under-estimated. Although having the greatest effect on insurers, the reform is in fact driven by government concern about the impact of lump sum awards upon National Health Service budgets in clinical negligence cases. Deferring the full payment of damages to later years is politically attractive, and gives the state an interest in how damages are paid. This interest was insufficiently acknowledged in the justifications provided for the reform, so that it appears to have been enacted for one set of reasons but in fact was enacted for another. This chapter therefore emphasises that there are sharp differences between the surface appearance of the legislation and the realities of tort law in practice.

Professor of Law, Cardiff Law School, Cardiff University. For their comments and assistance I am indebted to various Cardiff colleagues and to John Rousseau of the McKellar Group.

1 R Lewis, Structured Settlements: The Law and Practice (London, Sweet \& Maxwell, 1993) and I Goldrein and M de Haas (eds), Structured Settlements: A Practical Guide, 2nd edn (London, Butterworths, 1997). 


\section{The First Judicially Approved Structure}

Traditionally damages for personal injury in the UK were always paid by means of a lump sum, and never a pension. It did not matter that the compensation was for losses that might be suffered in the future: both the monthly wage that the accident victim may have lost, and the continuing costs of care that would have to be met, were compensated by one large payment. In recent years this once-and-for-all lump sum system has been subject to increasing criticism. In particular, it results in much uncertainty and imposes upon a claimant an enormous responsibility for safeguarding the future. Inflation and the vagaries of the returns on investment of the lump sum can result in rapid erosion of the compensation. As a result, a new form of payment via a structured settlement has made limited inroads into the use of lump sums. In effect, such a settlement usually converts the traditional lump sum into a series of payments derived from an annuity and these continue to be made no matter how long the claimant lives. In addition, these payments can be protected against price inflation and are free of tax.

These attractions of periodical payments were clearly illustrated in 1989 by the first judicially approved structure for a UK resident. Kelly $v$ Dawes arose out of a tragic road accident which took place three years earlier. Catherine Kelly was then a 22-year-old nurse, and was a passenger in a car driven by her husband, Andrew, a stonemason. ${ }^{2}$ Not far from their home they were involved in a road accident caused entirely by the negligence of the driver of the other vehicle. Both drivers were killed. Catherine lost the husband she had recently married, and suffered catastrophic injuries herself. The judge described the effect upon her as follows:

She was transformed from a lively young woman ... into a bedridden invalid with grossly impaired neurological functions, almost totally unaware of her surroundings, totally dependent on skilled nursing care and the devoted attention of her loving parents and family. Her condition will not improve for the rest of her life, in respect of which her life expectancy has been reduced to some 20 years. That figure is the product of a compromise medical view between doctors whose best guesses are on either side of the figure agreed. ${ }^{3}$

In seeking damages on her behalf, Catherine's father was keen to ensure that she would be looked after in a private nursing home for the rest of her life. Any money that might accrue to her estate upon her death was not an important consideration. Instead the major concern was that, given her uncertain life expectancy, the damages should be managed in order to ensure that, if she lived longer than the projected period, there would continue to be money to pay for her care. The best means of achieving this proved to be via a structure.

The settlement provided for most of Catherine's damages to be used to purchase an annuity from a life insurance company. The damages could be used in this way because there remained additional capital to provide a contingency fund for unexpected events. This reserve fund derived from the equity in Catherine's home, and from the estate she inherited from her husband, including the damages for his fatal accident. The annuity purchased with the damages was for an 'impaired life'. This meant that it provided a substantially higher annual return than a standard policy because the life insurer believed that the accident had reduced Catherine's life expectancy and the payments would therefore be made over a shorter period of time. In fact, for rating purposes the life office treated her as thirty-five years older than she actually was.

The major benefits of structuring the award were clearly revealed: the index-linked instalment payments were free of tax, and to last either for the rest of Catherine's life or for ten years, whichever proved longer. They would therefore ensure that she could continue to be kept at a private nursing home even if she lived beyond her projected span of years. Based on certain assumptions, the monies from a lump sum settlement invested in the conventional portfolio of fixed interest stocks and blue-chip shares would have been exhausted within twelve years, whereas the monthly payments under a structure would continue to be made. In addition, 
Catherine's father would not be subject to the stress of having to invest and be responsible for a lump sum greater than most people would encounter in their lifetime. Nor would the cost of obtaining investment advice have to be met. The financial advantages of the structure and the peace of mind it gave to the concerned relatives were clearly shown.

Ten years after the settlement Catherine's father spoke about his decision to seek periodical payments. He said:

I wanted the certainty of knowing that money would be available for the rest of Cathy's life. Looking back, the medical experts' view on her life expectation ranged from 5-10 years to 10-20 years. Physically, Cathy is in better shape now and if they come back today, they would say that she could live another 20-30 years from now. They got it wrong.... I have absolute peace of mind in knowing that, even if I am no longer here, there will still be money available for Cathy's needs for the rest of her life. ${ }^{4}$

\section{The Need to Impose Periodical Payments}

Since Kelly there have been over 1,500 seriously-injured people who have received part of their compensation in the form of periodical payments. ${ }^{5}$ However, further expansion of structured settlements has been hindered in several ways. One difficulty has been the refusal by many lawyers to give proper consideration to the merits of the alternative form of payment, even though they might be liable for failing to do so. ${ }^{6}$ Their reluctance to investigate structures has partly been attributed to the innate conservatism of the legal profession, ${ }^{7}$ together with ignorance or misconception of what might be involved. Sometimes structures have been raised as a possibility only at a late stage in the proceedings, by which time the claimant and his or her advisors have become used to the idea of receiving a lump sum and are suspicious of the change in approach. As a result, in practice, structures have been examined only in a minority of the cases in which they could have been sought. For example, in 2001-02 the National Health Service (NHS) paid over 500 claims in excess of $£ 100,000$ and yet less than ten per cent involved a structured settlement. ${ }^{8}$

The overall result has been that, largely through inertia, the lump sum has retained its dominance. A major factor in this has been the ability of either of the parties to object and thereby defeat with ease any proposed settlement based on periodical payments. ${ }^{9} \mathrm{It}$ is this

I Goldrein, M de Haas and J Frenkel, Personal Injury Major Claims Handling: Cost Effective Case Management (London, Butterworths, 2000) [17.168].

5 I estimate this figure on the basis of various statistics supplied over the years by the major intermediaries in the field. It sharply contrasts with the higher figures for various years reported by the Compensation Recovery Unit. Based on my own empirical work at the Compensation Recovery Unit, its figures are the result of clerical error and inaccurate coding.

$6 \quad$ R Lewis, 'A Lawyer's Duty to Consider a Structured Settlement' (1993) 9 Professional Negligence 126.

7 W Norris, 'Structured Settlements: Past and Future Developments' (paper delivered to the Legal Wales Conference, September 2003) (cited with author's permission). Similarly Lord Steyn could think of no substantial argument against judicial imposition of periodical payments other than 'the distaste of personal injury lawyers for change to a familiar system' in Wells $v$ Wells [1999] AC 345 (HL) 384.

Lord Chancellor's Department, 'Courts Bill: Regulatory Impact Assessment' (November 2002) table 1.

$9 \quad$ The need for the consent of both parties was affirmed as early as Burke $v$ Tower Hamlets (1989) Times, 10 August (QB). The point was reinforced by $R v$ Liverpool Health Authority et al ex p Hopley [2002] Lloyd's Rep Medical 494 (HC), discussed in R Lewis, 'Clinical Negligence and the NHS Refusal to Structure Settlements With Profit' (2003) 19 Professional Negligence 297. 
veto which is directly attacked by the new legislation. After lengthy consultation, ${ }^{10}$ the parties' veto was removed by the Courts Act 2003 with effect from 2005. ${ }^{11}$ Taking into account the needs of the claimant, a judge can make a periodical payments order (PPO) even if it is against the wishes of both parties. If a personal injury case comes to court and involves future pecuniary loss, the judge has no choice but to consider making a PPO. An order can be made even if not requested or wanted by the parties or where they envisaged an alternative award. The cases affected will usually be those involving serious injury where claims for future earnings or the cost of care are made. Although relatively few in number, these are much more likely to come before a court and to be in the public eye. They are also where the claimant is likely to be in the most need and in the greatest danger of being undercompensated. ${ }^{12}$ Although the court's power to make a PPO is limited, the threat of its use affects the bargaining position of the parties in most major cases.

\section{Limits on the Power to Impose Periodical Payments}

The power to make a PPO is limited in three particular respects. First, the power cannot be exercised in respect of damages for past pecuniary or non-pecuniary loss unless the parties agree. This means that only a minority of all claims in tort are in danger of having an order imposed because over 90 per cent involve only these two heads of damage and have no element of future loss. ${ }^{13}$ The typical claim is for a very small sum of money ${ }^{14}$ and it will

10 Lord Chancellor's Department, 'Damages for Future Loss' (Consultation Paper CP 01/02, March 2002) and its 'Analyses of the Responses' (CP(R) 01/02, November 2002). The Department addressed this issue more briefly in its previous paper, 'The Discount Rate and Alternatives to Lump Sum Payments' (Consultation Paper CP 3/00, March 2000). See also the Clinical Disputes Forum Discussion Paper, 'Lump Sum Damages and Periodical Payments' (2000) and the report summarising the responses (April 2002). With structures in their infancy in 1994, the Law Commission considered it premature to give judges the power to impose periodical payments in 'Structured Settlements and Interim and Provisional Damages' (Law Com No 224, 1994) [3.37] et seq. In a limited form periodical payments were recommended by Lord Pearson, 'Report of the Royal Commission on Civil Liability and Compensation for Personal Injury' (Cmnd 7054, 1978) vol 1, [573] [Pearson Report]. Earlier, reviewable periodical payments had been canvassed by the Law Commission, Working Paper No 41 (1971) but the response was so critical that the proposal was abandoned in its final report, 'Personal Injury Litigation: Assessment of Damages' (Law Com No 56, 1973).

11 The changes were made by ss 100 and 101 of the Courts Act 2003 which amended the Damages Act 1996.

12 For example, it is likely that certain claimants will be substantially under-compensated for loss of earnings. R Lewis, $\mathrm{R}$ McNabb, $\mathrm{H}$ Robinson and V Wass, 'Court Awards of Damages for Loss of Future Earnings: An Empirical Study and an Alternative Method of Calculation' (2002) 29 Journal of Law \& Society 406 and [2002] Journal of Personal Injury Law 151 and, by the same authors, 'Loss of Earnings Following Personal Injury: Do the Courts Adequately Compensate Injured Parties?' (2003) 113 Economic Journal F568.

$13 \quad$ Future pecuniary loss was found in only 7.5 per cent of cases, and comprised only 8.3 per cent of the total damages paid in tort. See the Pearson Report, above n 10, vol 2, at [44] and table 107.

$14 £ 2,500$ was the median figure in the survey of 81,000 cases receiving legal aid and closed in 1996-97 in P Pleasence, Personal Injury Litigation in Practice (London, Legal Aid Board Research Unit, 1998) 40, fig 3.17. In 70 per cent of successful cases the damages were less than $£ 5,000$, although the overall average was $£ 11,000$. P Fenn and N Rickman, 'Costs of Low Value Liability Claims 1997-2002' report average damages of only $£ 3,000$ for employers liability accident claims, although this study of 
continue to be disposed of by means of a lump sum. The preponderance of these small claims in the system is reflected in the fact that non-pecuniary loss accounts for about twothirds of the overall amount of damages awarded and past financial loss accounts for about a further quarter. ${ }^{15}$ However, these percentages change considerably in serious injury cases when future loss becomes much more important. For example, it has been estimated that, on average, 83 per cent of a claim exceeding $£ 250,000$ against the NHS comprises future loss. ${ }^{16}$ In addition, it must be emphasised that these few serious injury cases are responsible for a substantial amount of the overall total of damages awarded: in 2002 insurers estimated that although only 1 per cent of cases resulted in a payment of $£ 100,000$ or more, they accounted for 32 per cent of the total compensation received by claimants. ${ }^{17}$ It is in cases involving this level of damages, albeit a minority of all claims, where the new rules will have the greatest effect.

Second, a PPO can only be made if the continuity of payment is 'reasonably secure'. ${ }^{18}$ Legislation prescribes that the payments will be secure if either they are to be made by a government or health service body, ${ }^{19}$ or if they are protected by a compensation scheme which guarantees payment in the event of an insurer's insolvency. ${ }^{20}$ In effect, this means that orders can be made in the overwhelming majority of personal injury claims. One exception is that the Motor Insurers Bureau is not covered, but it has already been able to demonstrate successfully to a court that it is sufficiently secure for a PPO to be made in cases in which it is involved. ${ }^{21}$ Those against whom questions of security will be raised include Lloyd's syndicates, the medical defence organisations, offshore insurance companies, and private self-insured defendants. Even in these cases, a PPO can still be made and the security requirement met if the payments are arranged via the purchase of an annuity from a life insurer which is covered by the scheme guaranteeing payment in the event of insolvency.

The third and final limitation on the power to impose periodical payments is the most important in practice. The power can only be exercised if the case comes to court. Even though cases of serious injury are more likely to come before a judge, it remains the case that only a minority of them do so. ${ }^{22}$ Therefore, if neither party wants periodical payments to be considered, they can achieve their aim by settling privately for a lump sum. No matter what the court might have considered to be the needs of the claimant, the parties will get their wish

almost 100,000 cases related only to claims for less than $£ 15,000$. See <http://www.dca.gov.uk/majrep/claims/elclaims.htm> (date accessed: 17 July 2006).

As found by the Pearson Report, above n 10, vol 2, at table 107.

Lord Chancellor's Department, above $\mathrm{n} 8$, at table 3. However, in table 8 the Association of British Insurers estimated that only 46 per cent of the value of claims between $£ 100,000$ and $£ 250,000$ comprised future loss.

Lord Chancellor's Department, above n 8, at table 1.

Damages Act 1996, s 2(3) as amended by the Courts Act 2003, s 100.

As specified in the Damages (Government and Heath Service Bodies) Order 2005, SI 2005/474.

Financial Services and Markets Act 2000, s 213, discussed in detail in Annex C of Department for Constitutional Affairs, 'Guidance on Periodical Payments' (April 2005). Also acceptable are Ministerial guarantees under the Damages Act 1996, s 6.

Thacker v Steeples and the MIB (QB 16 May 2005;Lawtell Quantum AM 0900821) and Daniels v Edge and the MIB (2005) 15 Personal Injury Focus 23 (QB).

Before being set down for trial 98 per cent of cases are settled and many more are concluded before any hearing takes place: Pearson Report, above n 10, vol 2, at table 12. Similarly Pleasence, above $n 14$, at 12 reveals that only five out of the 762 'ordinary' cases with costs of less than $£ 5,000$ went to trial. However, a much larger percentage of serious injury cases end up in court. In cases involving very substantial awards of damages ten per cent of payments were found to be the result of formal court orders by P Cornes, Coping with Catastrophic Injury (Edinburgh, Rehabilitation Studies Unit, 1993) 20. 
for a lump sum deal if they keep their negotiations behind closed doors and avoid judicial involvement.

\section{Exercise of the Court's Discretion to Award Periodical Payments}

As noted, in any case involving future pecuniary loss the court must consider making a PPO. Whether it imposes such an order lies within its discretion and depends upon the particular facts of the case. The legislation offers only limited guidance about what might affect this decision. The most important consideration is the claimant's needs. ${ }^{23}$ Only in a Practice Direction is the court referred to the secondary issue of whether either of the parties prefers a lump sum and their reasons for doing so.

The emphasis on the claimant's needs is novel: it is not to be found in earlier legislation dealing with damages. Need never affects compensation for lost earnings or pain and suffering, for example, although it is implicit in any assessment of housing or nursing care costs. Need is notoriously difficult to define ${ }^{24}$ but focusing on it can produce a different perspective on an award. It contrasts with the usual objective in tort of returning the claimant to the pre-accident position. In particular, need requires a more detailed analysis of the claimant's future than the tort system has previously attempted.

Apart from need, the court must also have regard to the nature of any financial advice received by the claimant. This advice will rarely be that of the claimant's own solicitor, because legislation prevents financial advice being given by those who are not authorised. ${ }^{25}$ Instead the court will require the opinion of an independent financial advisor. This will have to be sought early in the proceedings because, as soon as is reasonably practicable, the court is required to give the parties a preliminary indication of which form of payment it considers the more appropriate. ${ }^{26}$ Financial intermediaries will therefore have an even more important part to play than they did in the past with structured settlements, for then they were often involved only at a late stage. The projections of these experts concerning the extent that the lump sum will be eroded compared to the constant value of the periodical payments will be crucial in determining the form of the award, and their opinion will now be given at an early stage in the proceedings.

The court must also consider 'the scale of the annual payments taking into account any deduction for contributory negligence'. ${ }^{27}$ One area of uncertainty is the level of damages below which it might not be worthwhile to move towards a periodic award because its size may not merit the time and trouble involved. Under the old rules the court had to be satisfied that a structured settlement had been considered by the parties in any case involving damages for future loss of $£ 500,000$ or more. ${ }^{28}$ However, for a periodical payment under the new rules Ministers concluded that the size of an award should not be the determining factor. Perhaps they had in mind the experience of the US, where structured settlements have become commonplace even at damages levels below $£ 100,000$. Instead of setting a damages threshold, therefore, the government has left the court to assess only whether

Civil Procedure Rules 1998, r 41.7 as amended by SI 2004/3129.

For the most recent assessment of the difficulties involved see M Tibble, 'Review of Existing Research on the Extra Costs of Disability' (Department of Work and Pensions, Working Paper no 21, 2005).

Financial Services and Markets Act 2000, Sch 6.

Civil Procedure Rules 1998, r 41.6. See J Stone and A Sands, 'Periodical Payments: The Need for a Pragmatic Approach' (2005) 15 Personal Injury Focus 18.

CPR Practice Direction 41B, 1(1).

Former RSC Practice Direction 21[6.4]. The practice of the NHS was to consider a structure in any case having a minimum value of $£ 250,000$. 
arranging the award in a new form might involve disproportionate effort. ${ }^{29}$ Although in theory any award of future loss could therefore be paid periodically, in practice a PPO will be less appropriate for certain types of claim. For example, although there is nothing to prevent a court imposing an order no matter what the age of the claimant, the objection of an elderly person to being paid periodically might be expected to have more force given the shorter duration of the payments. ${ }^{30}$

Another factor affecting the level at which a PPO may be made and the extent they will be used is that, in most serious injury cases, the claimant should be left with a contingency lump sum fund to meet unexpected needs. It is essential that this element of flexibility exists to safeguard the future, even though it is not mentioned in the legislation. There are fears that judges will not take it into account sufficiently. ${ }^{31}$ Capital may be needed not only to buy and adapt accommodation, but also to care for the claimant, for example in the event of the unexpected death or divorce of his or her carer spouse. Capital might also be needed if, as expected, care costs outpace price inflation. For structured settlements in the past, on average, only about half of the award was used to arrange the periodic payments. The remainder was accounted for by interim payments, the capital needed to discharge debts and pay for immediate purchases, and the contingency fund. ${ }^{32}$ Will judges take a similar approach?

One area of concern with regard to when an order may be made is whether the award of damages is to be reduced for contributory negligence. This may not become apparent until a late stage in the proceedings, and yet it could be crucial in influencing the financial adviser as to the form of the award. If there is to be a reduction in damages, a PPO may not then be enough to pay the cost of the claimant's immediate nursing needs. It might then be thought better to award a lump sum. Although that payment is more likely to be exhausted earlier if not within the tax shelter provided by periodical payments, it may be preferable for this to occur and for the claimant's actual needs to be met for only a short time, rather than leaving a permanently inadequate source of funds to offer insufficient protection against needs which have yet to occur.

\section{A Change to the Method for Assessing Damages}

Where periodical payments are thought appropriate, the court is required to make a fundamental change in the way that it calculates damages: instead of a 'top-down' approach it must adopt a 'bottom-up' approach, ${ }^{33}$ thereby focusing more precisely upon the claimant's needs.

The more familiar top-down approach begins only after arriving at the traditional lump sum. It then calculates the income stream which can be derived from that capital, and this can be used to assess whether it will meet the claimant's annual needs. This top-down approach does not avoid the most serious criticisms made of lump sums: the need to forecast how long the payments will be required, and the rate of return, after taxation and inflation, which could be obtained from investment of the lump sum. In particular, the claimant's life expectancy is

29 Department for Constitutional Affairs, 'Guidance on Periodical Payments' (April 2005) [9]. See <http://www.dca.gov.uk/pubs/pps-guidance-final.pdf> (date accessed: 17 July 2006).

30 The life expectancy of the claimant is mentioned as a factor in Explanatory Note 356 to the Courts Act 2003, but is not referred to elsewhere.

$31 \quad$ N Leech, 'New Rules Could Prove Damaging' (2005) 10 Legal \& Medical 25 and A Sands, 'Periodical Payments—the Development of a Pragmatic Approach' (2006) 74 Medico-Legal Journal 69. See also the Master of the Court of Protection, D Lush, 'Damages for Personal Injury: Why Some Claimants Prefer a Conventional Lump Sum to Periodical Payments' (2005) 1 London Law Review 187, 191.

32 Lewis, above $n$ 1, at [9]-[66] et seq where the factors affecting the size of the contingency fund are examined in detail.

33 Ibid, at [9]-[10] et seq. 
usually an element in estimating how long the payments will be required. It is usually only after the lump sum has been calculated using these traditional methods that it is used in a structured settlement to transfer from the claimant to an insurer the risk of the claimant living beyond his or her estimated life expectancy. This is usually achieved by the liability insurer using the lump sum to purchase annuities from a life office to provide a stream of payments for as long as the claimant actually lives. Structures, therefore, usually involve only changing the form of payment after the parties have gone through the traditional approach and, as a result, they retain many of the disadvantages of the lump sum.

By contrast, for a PPO the new legislation requires a bottom-up approach. Unlike top-down, this does not require the lump sum to be calculated at all. Instead, irrespective of the capital cost, the court assesses the periodical payments the claimant needs for the future and orders that they be index-linked and paid for the duration of the loss, this often being the claimant's lifetime. Unlike under the traditional form of payment, it is the defendant who is burdened with both the risk of the investment return and the longevity of the claimant.

Overall a complex budget for life may be needed, and there is great pressure to 'get it right'. ${ }^{34}$ Detailed planning of the claimant's future is encouraged by allowing the payments to increase in steps, or even decrease ${ }^{35}$ However, these variations in payment can only take place if the court specifies in the original order the precise dates for the changes to take effect. The court is encouraged to plan for a variety of factors including those affecting earnings (the claimant ceasing to work, or gaining a promotional increase in pay) and affecting care (loss of the existing gratuitous carers, or changes in the medical condition).

The crucial difference from previous practice is that the court is not concerned with the lump sum cost of providing for these needs. Nor does it have to speculate for how long there will still be such need. Clairvoyant estimates of how long the claimant will live, for example, are made redundant. In addition, there is no need to speculate about the returns possible upon investment of a lump sum. There is no place for the 'Ogden Tables'. ${ }^{36}$ Multipliers and discount rates are otiose: no multiplier is required to reflect the period of years of the loss in order to convert it into an immediate capital amount, and no discount rate is needed to convert the future stream of financial losses into a capital sum representing present day values. It is the defendant who must now assume liability over time for these risks.

\section{The Impact on the Bargaining Power of the Parties}

It would be a mistake to assume that because new legislation has been passed it will necessarily be used in the way intended by the drafters. The legal rules provide a framework for bargaining between the parties, and the results can be very different from the picture of litigation envisaged by the black-letter lawyer. Within the shadow of the new rules it is likely that a number of claimants will try to take advantage of the removal of the defendant's veto: they will threaten to take the case to court and burden the defendant with a PPO involving uncertain liabilities unless there is agreement to a higher lump sum than previously was on offer. Exactly the same tactic has been used to extract a larger lump sum when the power to award provisional damages has been in issue.

Somewhat less successfully, insurers may also use the threat of periodical payments to bargain harder with a claimant who is set on receiving a lump sum, or worried about whether the court's assessment of needs will correspond to his or her own. Can a judge be trusted to leave enough of a contingency lump sum fund to provide for unexpected events? Claimants may also be concerned that even an index-linked settlement may not be enough to pay for their future care costs. Because of these worries bargains will be struck to settle out of court. The experience of other countries is that these deals have undermined the power to make

Law Commission, 'Structured Settlements and Interim and Provisional Damages' (Consultation Paper No 125, 1992) [3.19]. 
periodic awards to such an extent that 'lump-sum settlements have like termites reduced the [periodical payments] rent system to but a hollow shell'. ${ }^{37}$ Because negotiations between the parties will water down the effect of the reform we can expect lump sums to be commonly used even in the majority of serious injury cases involving future financial losses. But the possibility of imposing a PPO substantially influences the bargaining position of the parties, and it is in that sense that all serious injury cases are affected.

The move towards imposing an uncertain liability upon defendants is likely to strengthen the claimant's hand more than that of the defendant. However, it is important to consider the effect of the changes upon the mechanics of making a deal. In particular, for costs purposes, how is it to be determined whether offers to settle made by either of the parties are reasonable when one of them is based on the traditional lump sum and the other is based partly on an assessment of the claimant's annual needs? In complex cases there could be a mixture of approaches depending upon different care regimes and earnings losses. How is the court to assess the reasonableness of the rejection of a periodical payments offer if it is not based on its capital value but on wider social and family reasons? Although the Civil Procedure Rules specify that costs consequences follow if the court judgment is not 'more advantageous' than the other party's offer, the Rules do not specify what may constitute an advantage in the context of periodical payments. ${ }^{38}$ As a result there is scope here for clever tactics from skilled litigators. ${ }^{39}$ It remains to be seen whether the broad discretion given to the court as to costs will be further used to encourage litigants to negotiate on a periodical payments basis. The attitude and training of the judiciary will be crucial in determining the long-term success of the new provisions.

\section{Why Costs for Insurers Will Increase}

Although insurers are faced with a variety of technical and administrative problems as a result of the new legislation, their main concern is the increased cost of settlements. Insurers will have to pay substantially more to fund a PPO than a traditional lump sum, and the government failed to anticipate this. The regulatory impact assessment for the legislation argued that the reforms 'would not materially increase the value of claims', ${ }^{40}$ even suggesting that liability insurers might save four per cent by purchasing annuities rather than using lump sums. This is far from the case, and the suggestion that there were savings to be made came as a shock to those with knowledge of the compensation industry: it was based upon 'spurious assumptions'. ${ }^{41}$ The policy implications of the reforms must be looked at afresh.

To understand why the regulatory impact assessment was so very wide of the mark we must consider how most compensators will provide for their liability to make index-linked payments for an uncertain time and for an unknown total cost. Liability insurers will almost always fund PPOs by purchasing annuities from a life insurer. A possible alternative method open to large composite insurers is to self-fund the payments by using the facilities of their own life offices, but there is little enthusiasm for this, and in the past it was almost never done for structured

JG Fleming, 'Damages: Capital or Rent?' (1969) 19 University of Toronto Law Journal 295, 299.

Civil Procedure (Amendment No 3) Rules 2004, SI 2004/3129 inserting the new $r$ 36.2A.

39 Association of Personal Injury Lawyers (APIL), 'Periodical Payments and Part 36: A Response' (14 April 2004) fears that the uncertainty introduced makes it difficult for lawyers to advise their clients, and claimants will be unfairly disadvantaged. The Master of the Court of Protection notes that the reasons for resisting lump sums could be 'not simply financial but extend across a much broader range of considerations-medical, social and personal-and more holistic insofar as they treat the claimant as a member of a family rather than in isolation'.: Lush, above n 31, at 203. 
settlements. Unlike insurers, public bodies such as NHS trusts are able to self-fund the payments from their own resources because they are able to satisfy the security requirement in the legislation. However, most other defendants will be forced into the annuity market to fund PPOs. This could prove difficult and very expensive for them because there are only a small number of suitable financial products available and only at a high cost.

There are two main reasons for this difficulty and expense. First, there is little competition in the market to provide annuities for tort claimants. This has the effect of making quotations less keen than, for example, in the US where there are at least 15 annuity providers. By contrast, in the UK at the end of 2003 there was a real danger that there would be no life insurers involved at all. This would have completely undermined the planned reforms. Fortunately, a couple of new providers have now emerged but the market remains fragile. ${ }^{42}$ Life insurers are deterred because few such annuities are sought, the market being of almost no significance compared to that for annuities for retirement pensions. There is a marked contrast with the $£ 6$ billion a year spent on structured settlements in the US. Another discouraging factor is the particular difficulty of underwriting annuities for the 'impaired lives' of many of the injured claimants. When there is only limited experience of the effect of injury on life expectancy, underwriting becomes far more an art than a science, and a miscalculated gamble can prove costly. As a result the market is limited, premiums have fluctuated widely, and the cost of annuities is high. Yet it remains of crucial importance to the future of PPOs, and the government has been urged to intervene to stabilise matters. ${ }^{43}$

The second factor which drives up the cost of annuities is linking them to increases in the Retail Prices Index (RPI). This results in regulatory restrictions being imposed upon the providers. Life insurers are required by the Financial Services Authority to meet their solvency requirements by providing assets which closely match their liabilities. In practice this means that to fund RPI annuities they have to purchase index-linked gilts issued by the government. These are expensive to buy, the market for them being dominated by pension funds anxious to meet their own statutory obligations to obtain matching funds for their index-linked returns. In addition, the government has made too few of these gilts available to the market. ${ }^{44}$ Because of the high demand and the limited provision the yields have been very low. In turn, this means that the RPI annuity rates offered by providers are poor value. Where the topdown approach is used to arrange a settlement these rates make it difficult to ensure that the periodical payments derived from the traditional lump sum will meet all of the claimant's needs. With bottom-up arrangements under a PPO, defendants can now be forced to make RPI linked periodical payments whatever the cost. If they do not self-fund, they will be forced to purchase annuities in this limited market.

The overall result for liability insurers is that it will be much more expensive to purchase annuities to fund the payments under a PPO than to hand over the traditional lump sum. Anecdotal evidence suggests that the cost of these settlements has increased by as much as a quarter or even a third, and insurance reserves have been revised accordingly. ${ }^{45}$ One barrister has suggested that the PPO regime:

42 The volatile life market was analysed in Lewis, above $\mathrm{n} 1$, at ch 11 . For the recent history of providers see A Ritchie et al, Kemp \& Kemp: Personal Injury Law, Practice and Procedure (London, Sweet \& Maxwell, 2005) vol 1, 22-061.

43 For example, APIL have asked that relevant discussion between the Department of Trade and the Department for Constitutional Affairs be given higher priority: APIL, 'Periodical Payments: An Assessment of Concerns and Solutions' (March 2004).

$44 \quad$ Gilts are bonds issued by the UK government. Indexed linked gilts were first issued in 1981 and the last but one was issued in 2002 with a final date for redemption in 2035. Government was repeatedly urged by insurers, APIL and others to issue more gilts, and it eventually complied in September 2005 when it made available a new issue with a maturity date of 2055 . The issue was immediately over-subscribed.

$45 \quad$ M Hardman, 'Periodical Payments: A Defendant Lawyer's Perspective' (paper presented to a conference at the Institute of Actuaries, March 2005). The paper can be accessed at 
is going to cost insurers, both directly and indirectly, a lot more money and expense to service these damages. I do not believe that they have, as yet, appreciated the extent of their troubles. ${ }^{46}$

One case that was settled privately on an RPI basis illustrates this. If settlement had been based upon the traditional lump sum the multiplier would have been 29. However, funding RPI periodical payments in effect increased the capital sum needed to purchase the annuities such that the corresponding multiplier rose to 45 . The cost of future financial loss therefore rose by 55 per cent. ${ }^{47}$

\section{The Political Reasons for the Reform}

As we have seen, there are strong arguments to support the more widespread use of periodical payments. Many of these focus upon the needs of claimants and the desirability of providing compensation equivalent to that which has been lost. On the surface the government can be seen to be supporting a fairer system which helps ensure that compensation meets needs and is used for the purposes for which it was awarded. These are the only reasons for the reform listed by the Department for Constitutional Affairs in the guidance it provides. ${ }^{48}$ But if we look at the organisations that gave the most support to the new legislation we get a different picture of the reasons why it was passed.

The Association of Personal Injury Lawyers is a claimant lawyers' organisation, very active in test-case litigation and in lobbying the government. Although generally in support of periodical payments as a means to ensure full compensation of victims, it opposed the imposition of PPOs against claimants' wishes unless there were exceptional circumstances. ${ }^{49}$ Not surprisingly, insurers, together with the defence organisation, the Forum of Insurance Lawyers, were not in favour of the reform. Nor was change sought by the intermediaries who arrange structured settlements. Frenkel Topping, the innovative firm responsible for arranging the great majority of such deals, has been influential in previous reforms. But it opposed PPOs on the ground that they would unduly interfere with the consensual approach. In total, only a bare majority ( 57 per cent) of respondents to the Lord Chancellor's consultation paper gave an unqualified welcome to imposition.

Instead the catalysts for the reform lay within the government itself. Although the legislation was the prime responsibility of the Lord Chancellor's Department, it had no enthusiasm to make the change urgently. However, both the Treasury and the Department of Health were keen supporters of immediate action, and they were the driving forces behind the sudden implementation of the enabling legislation. Parliamentary time was found by inserting the relevant provisions, rather anomalously, into a bill dealing with criminal law and administration. Claimants' interests were very much secondary to those involving public finance and the demands of the NHS. Far from being what they appear on the surface, the reforms in fact were politically driven.

The political and economic advantages to the government of periodical payments are as follows. In contrast to the problems faced by liability insurers, the government bodies such as the Ministry of Defence and especially the NHS will make immediate gains. This is because

<http://www.actuaries.org.uk/Display_Page.cgi?url=/damages/seminar20050307.html> (date accessed: 17 July 2006).

46 R De Wilde, 'Periodical Payments-A Journey into the Unknown' [2005] Journal of Personal Injury Law 320, 325.

47 Details of this case must remain confidential. It must be remembered that the increase would not apply to the lump sum element of the damages which should form a contingency fund and which would be a substantial element in most settlements.

48 'Guidance on Periodical Payments' (April 2005) [6]-[8].

49 APIL, 'Response to the Lord Chancellor's Consultation Paper' (May 2002) 
their budgets will no longer be denuded by the loss of large capital sums paid as damages. ${ }^{50}$ Their cash-flow will be improved because they can self-fund the periodical payments and they are not required to enter the expensive annuity market. It was forecast that in the first year of the new regime the NHS could save as much as $£ 245$ million out of the $£ 330$ million it would otherwise have to pay for the larger claims. ${ }^{51}$ This cash-flow saving will continue at a diminishing rate for 24 years until the accumulated liabilities reach, and thereafter outgrow, what would have been the capital sums needed to dispose of the claims entirely. That is, at that time not only will the good times come to an end and have to be paid for, but also there will be a real and increasing additional cost to the public purse. This cost may be relatively small in relation to the entire NHS budget, but government finances should beware of these contingent liabilities, especially in the light of current concern about whether we should be paying more to fund future pensions in general. In the past, damages awards have had dramatic effects upon individual heath care budgets: major capital expenditure has been deferred and even wards have closed. At present, health trusts in England are running at a deficit which soon could reach a billion pounds. ${ }^{52}$ It is not therefore surprising to find that the $\mathrm{NHS}$ has welcomed the new regime, and is much more likely than liability insurers to take advantage of it by forcing claimants to accept periodical payments. For many years it has selffunded all its structured settlements, and it now self-funds all its PPOs. It refuses to buy annuities from outside providers. The savings in cash-flow are too good to miss.

Although the reforms were driven by the NHS, it is important to note that clinical negligence comprises only a minority of claims even if the focus is confined to serious injuries. Liability insurers remain the predominant paymasters. The NHS was responsible for only 11 per cent of all personal injury claims resulting in an award of over $£ 100,000$ in 2001-02. For claims of this size in that year liability insurers paid out over £2.26 billion, almost six times as much as the NHS's $£ 0.4$ billion. ${ }^{53}$ This statistic reveals how the emphasis has been misplaced, and how in this reform the NHS tail is wagging the insurance dog. In the great majority of cases it will be liability insurers and premium payers who will have to bear the increased costs resulting from the reforms, whilst in only the minority of cases, in the short-term, it will be the taxpayer who benefits.

This is only one of several areas in which changes have been made which result in an increase in tort damages but also transfer costs from the public to the private sphere. Insurers have recently been made to bear the cost of the removal of legal aid and the introduction of conditional fees. They now pay the claimant's costs, including the solicitor's success fee and the insurance premium against the possibility of losing. Insurers also have been required to pay for the cost of providing social security benefits to accident victims and, more recently, for

In 2001-02 the MOD paid out £81million in compensation according to the National Audit Office, 'Ministry of Defence: Compensation Claims' (HC 957 2002-03). By contrast, in the same year the NHS paid out more than five times as much, amounting to $£ 446$ million according to the Department of Health, 'Making Amends: A Consultation Paper Setting out Proposals for Reforming the Approach to Clinical Negligence in the NHS' (2003) table, 60. For wider statistical analysis see R Lewis, A Morris, and K Oliphant, 'Tort Personal Injury Claim Statistics: Is there a Compensation Culture in the UK?' (2006) 14 Torts Law Journal 158 and [2006] Journal of Personal Injury Law 87.

51 Lord Chancellor's Department, above $\mathrm{n} \mathrm{8}$, at table 14. This is based on converting into periodical payments 80 per cent of all awards over $£ 250,000$ and 40 per cent of all awards between $£ 100,000$ and $£ 250,000$.

52 G Jones, 'NHS told to cut costs as Hewitt confirms spending squeeze' The Daily Telegraph (London 18 January 2006), and 'NHS on critical list as cash crisis spirals' The Times (London 26 January 2006). Up to fifty trusts were said to have lost control of their finances. Those in most difficulty revealed they had closed beds, wards or entire hospitals. Others had cancelled operations and cut staff levels. However, in the last three years the overall expenditure on the NHS has grown rapidly from $£ 65$ billion in 2002-03 to £87 billion in 2005-06. 
the cost of their NHS treatment. ${ }^{54}$ As a result of the present reforms they now must bear the brunt of further savings in public expenditure. Of course, the transfer results in a 'stealth tax' which all premium payers and, ultimately, society at large must pay. Tort law, whether made by judges or Parliament, has always been influenced by politics in the wider sense, ${ }^{55}$ and this is especially apparent in the recent and continuing struggles that are taking place over damages law.

\section{Canadian Comparisons}

Given the conference for which this chapter was originally prepared, it is appropriate to outline a Canadian context within which comparative work could be done in this area. Although structured settlements in Canada pre-date those in the UK, they have generated little academic interest. ${ }^{56}$ Following empirical research in both countries, I compared the two regimes in an article published some years ago, ${ }^{57}$ but present Canadian academic texts devote little, if any, space to the subject. This is in spite of continuing legislative efforts in Canadian provinces to introduce an element of compulsion into the previously consensual periodical payment regimes. Reflecting on these legislative changes, Frank McKellar, the leading structured settlement intermediary, has recently concluded that there has been 'a steady regulatory drive towards mandatory court-ordered structured settlements'. ${ }^{58}$ Here is a major area of tort law in which 'emerging issues' comparable to those in the UK arise, yet which has not been subject to academic scrutiny.

There are six provinces in which there is legislation which enables courts to impose PPOs against the wishes of at least one of the parties. These are Ontario, Manitoba, British Columbia, Nova Scotia, Quebec and, most recently, Alberta. ${ }^{59}$ One basis for making such an award is where the plaintiff requests that damages be increased to allow for the income tax that must be paid when the compensation is invested. The legislation then allows defendants to apply for an award of periodical payments, and the court may order such payment even if opposed by the plaintiff. The justification for this is that periodical payments are free of tax, and this obviates the need for damages to be grossed-up. In the UK the claimant does not seek such additional monies because the discount rate, in theory at least, already makes allowance for the tax that will be collected from the income that arises on investment of the damages.

The limits on the use of PPOs vary in each province. The Quebec Civil Code makes the most limited provision: periodical payments can only be imposed in cases involving minors. ${ }^{60}$

$54 \quad$ For recovery of social security and NHS treatment costs see R Lewis, Deducting Benefits From Damages For Personal Injury (Oxford, Oxford University Press, 1999) and R Lewis, 'Recovery of NHS Accident Costs: Tort as a Vehicle for Raising Public Funds' (1999) 62 MLR 903. Recovery has been extended by Part III of the Heath and Social Care (Community Health Standards) Act 2003. Hypothecation, in theory, then returns the money collected for the cost of treatment to the appropriate specific hospital trust or other NHS budget.

55 R Lewis, 'Lobbying and the Damages Act 1996: "Whispering in Appropriate Ears"' (1997) 60 MLR 230.

56 The notable exception is JP Weir, Structured Settlements (Toronto, Carswell, 1984).

57 R Lewis, 'Structured Settlements of Damages Awards in Britain and Canada' (1993) 42 ICLQ 780 .

$58 \quad$ P Chisholm, 'Province has Plans for New Compulsory Structures' Law Times (Aurora 12 December 2005).

59 For Alberta see the Insurance Act RSA 2000 c I-3, s 650.2, under which no regulations have been made, and the Justice Statutes Amendment Act SA 2004 c 11, s 3 , amending the Judicature Act RSA $2000 \mathrm{c} \mathrm{J-2}$ and in force from 30 June 2006. 
Manitoba ${ }^{61}$ and Nova Scotia ${ }^{62}$ make the widest provision, enabling courts to exercise the power in any claim for personal injury or death. An Ontario statute confines the power to cases in which a tax gross-up is sought. ${ }^{63}$ This is further limited in British Columbia by applying only to claims arising from the use of a motor vehicle, although the power can also be exercised in any motor vehicle case even if no gross-up is sought, provided that the pecuniary loss is at least $\$ 100,000 .{ }^{64}$ Regulations under a second statute in Ontario ${ }^{65}$ similarly make special provision for motor vehicle accidents irrespective of gross-up by allowing a PPO if any two of the following four conditions are satisfied: the award is for more than $\$ 100,000$, the plaintiff is aged under 18 , the plaintiff has no other means to fund future care, and the plaintiff is not likely to manage the award in a prudent manner.

Except in Manitoba and Nova Scotia, the power of the court to order a PPO is expressly prohibited if it is against the 'best interests of the plaintiff'. Generally this is interpreted as giving the court a wide discretion. In British Columbia the effect has been that, subject to notable exceptions, the court usually defers to the wishes of the plaintiff. ${ }^{66}$ The factors applied by the various Canadian courts could prove instructive for any practitioner or judge in the UK trying to interpret the new powers to impose PPOs.

There are obvious differences in the scope of the Canadian and UK legislation, but let us focus here upon the justifications for the statutes. The tax gross-up which distinguishes the regimes in the two countries has already been discussed. Apart from this factor it may appear on the surface that the legislation in both countries has been concerned primarily with protecting claimants. However, this chapter has exposed the limitations of such a perspective as far as the UK is concerned. Should a similar reservation be made concerning the Canadian position? On the surface there is a case for doing so because, in practice, many Canadian defendants find structures attractive propositions. But can we trace any concern about escalating medical costs and the benefits that might accrue to the state from the use of PPOs-factors which have so influenced developments in the UK? There is at least some evidence of these factors being relevant in Canada. In 2005 an Access to Justice Bill in Ontario proposed that for medical malpractice cases alone courts should be forced to use periodical payments to compensate for the cost of future care. ${ }^{67}$ By making this change the Ministry of Health and Long-term Care hoped to save over $\$ 12$ million a year. ${ }^{68}$ Although the Bill failed, the subject is still under review. Overall, however, we remain unsure of the influences upon, and the effect of, the PPO legislation in the Canadian provinces. It is an 'emerging issue' in need of further comment and analysis.

Court of Queen's Bench Act CCSM c C280, s 88 as applied in Lusignan v Concordia Hospital (1997) 117 Man R (2d) 241 (QB).

62 Automobile Insurance Reform Act SNS 2003 c 1, s 26 which, despite its title, is not confined to motor accidents and was based on the Manitoba legislation. See also the Nova Scotia Barristers Society, 'Information Paper on the Use of Court Ordered Structured Settlement in Nova Scotia' (2002). See <http://www.nsbs.ns.ca/notices/struc_set_discus.htm> (date accessed: 17 July 2006) and the Law Reform Commission of Nova Scotia, 'Court-ordered Structured Settlements for Personal injury Damage Awards' (2004).

63 Courts of Justice Act RSO 1990 c 43, s 116, as applied in the medical malpractice case of Chesher v Monaghan (2000) 48 OR (3d) 451 (CA).

64 Insurance (Motor Vehicle) Act RSBC 1996 c 231, s 55.

65 OReg 461/96, s 6, enacted under the Insurance Act RSO 1990 c I.8.

66 Contrast Abraham v Abbinante (1998) 55 BCLR (3d) 150 (SC) and Lee $v$ Dawson (2003) 17 BCLR (4th) 80 (SC) with the order made in O'Brien $v$ Anderson (2001) 91 $\operatorname{BCLR}(3 d) 137$ (SC).

67 Bill 14, Access to Justice Act, 2006, 2d Sess, 38th Parl, Ontario. The bill received first reading 27 October 2005 and carried second reading 11 April 2006.

68 Ontario Trial Lawyers Association, 'Submissions on Taxation and Payment of Personal Injury Awards' (2004). See <http://www.otla.com/Content.asp?page=news > (date accessed: 17 July 2006). 


\section{Conclusions}

In the UK, how important is the new judicial power to award damages in a form other than that sought by the parties? A former President of APIL has called it 'perhaps the most important development ever relating to the law of damages'. ${ }^{69}$ Similarly, insurers have described it as:

the most fundamental change in 150 years in the quantification of bodily injury claims involving continuing losses. The changes will affect not only the level of damages awarded but will also require a new approach to the quantification of claims. ${ }^{70}$

It is true that the reform undermines the traditional approach to damages, first by requiring bottom-up assessments which focus upon claimants' annual needs, and second by guaranteeing that these needs will be satisfied no matter how long the claimant actually lives and whatever the level of price inflation. These needs are to be met irrespective of the resulting lump sum cost. In addition, the parties must give early consideration to the form in which the damages are to be paid. A change is thus being sought not only in legal method, but also in the culture of personal injury practitioners.

However, the effect of the legislation may be less profound and certainly much harder to see if it is hidden in the settlement system, and predominantly results only in insurers paying higher lump sums than otherwise would be the case. There is every incentive for insurers to settle privately in this way in order to avoid the cost and difficulty of arranging the annuity payments usually required to satisfy a PPO. The legislation failed to anticipate the problems insurers have in accommodating the new regime within their wider financial world. Because of the difficulties insurers will be keen to maintain the traditional form of settlement. Even if this proves to be the case, it can still be argued that the reform is important because all serious injury cases are affected by the threat of imposition of a PPO, whether or not they eventually come to court. The potential exercise of the power generally strengthens the claimant's hand and affects the bargains that are struck in the tort system.

In one way or another, therefore, the changes will result in many seriously injured claimants obtaining more money at the expense of insurance companies. But also to benefit from the legislation is one group of defendants-government departments and public bodies, especially the NHS. Unlike insurers, they can self-fund the periodical payments and thereby retain within their budgets the capital sums they would otherwise have to pay. They can avoid paying for today's liabilities until tomorrow. This effect upon public expenditure was not among the main reasons put forward for the reform. However, in exposing the true costs and benefits of the legislation, this chapter has revealed a political dimension which could easily be overlooked by the casual observer.

In spite of their importance, these changes have been implemented without apparent detection by academics. Tort scholarship is very partial. It is extraordinary how much attention is focused upon issues of liability as opposed to the quantum of damages. Practitioners are bemused by the pre-occupation of academics with the rules on fault: they are aware that liability is infrequently challenged by insurers-being raised as a preliminary issue in only about 20 per cent of their cases ${ }^{71}$ - whereas the amount of compensation is almost always open to some negotiation. This chapter goes a little way towards redressing the imbalance in tort scholarship. The traditional tort textbook can leave the reader with a very misleading

C Ettinger, 'Compensating for Future Loss' (2005) 155 New Law Journal 525. His views are repeated by his successor as APIL President, A Gore, in APIL, 'Annual Report' (2005) 5.

70 London International Insurance and Reinsurance Market Association, Third UK Bodily Injury Awards Study (London, International Underwriting Association of London, 2003) 83.

71 T Goriely, R Moorhead and P Abrams, More Civil Justice? The Impact of the Woolf Reforms on Pre-Action Behaviour (London, The Law Society and the Civil Justice Council, 2002) 103. However, liability was more readily denied in another survey conducted by APIL, 'Potential Impact of the Threshold Limit for Personal Injury Cases within the Small Claims Court being raised to £5000' (2005). 
impression about how the compensation system operates in cases of personal injury. ${ }^{72}$ In practice, the system is transformed into something which has but a limited relationship to the theoretical picture portrayed. But it is not only the experience of practice which throws down a challenge to tort scholars: it is also changes to the basic rules themselves. These new rules undermine the tradition of awarding damages in a once-and-for-all lump sum, and expose the fragility of the conventional claim that the aim in tort is to return the claimant, in so far as possible, to the position enjoyed before the accident. As such they raise fundamental questions concerning the rationale and future direction of the law of tort. Who really pays, how much, and in what manner, are questions that will not go away. ${ }^{73}$ 